UDC 615.9

DOI: 10.21668/health.risk/2021.2.11.eng

Research article

\title{
METAL-CONTAINING NANOPARTICLES AS RISK FACTORS CAUSING PATHOMORPHOLOGICAL CHANGES IN INTERNAL ORGANS TISSUES IN AN EXPERIMENT
}

\author{
N.V. Zaitseva ${ }^{1}$, M.A. Zemlyanova ${ }^{1}$, A.M. Ignatova ${ }^{1,2}$, M.S. Stepankov ${ }^{1}$, Yu.V. Koldibekova ${ }^{1}$ \\ ${ }^{1}$ Federal Scientific Center for Medical and Preventive Health Risk Management Technologies, 82 Monastyrskaya \\ Str., Perm, 614045, Russian Federation \\ ${ }^{2}$ Institute of Continuous Media Mechanics, the Ural Branch of the Russian Academy of Science, 1 Akademika \\ Koroleva Str., Perm, 614013, Russian Federation
}

Given wide spread of nanomaterials, it seems vital to estimate and predict changes in internal organs tissues under exposure to metal-containing nanoparticles that are risk factors causing negative effects occurring in critical organs and systems. It requires revealing objective procedures that can be used to quantitatively assess risks of pathologic changes in tissues that at present have only qualitative properties.

Our research goal was to quantitatively assess risks of lung diseases occurrence in rats exposed to metal-containing nanoparticles (exemplified by nano-sized $\mathrm{CuO}$ ) using image analyzing procedures.

We examined toxic effects produced by nano-disperse $\mathrm{CuO}(45.86 \mathrm{~nm})$ under inhalation (a single and 14-day multiple) exposure and oral exposure (for 20 days); the experiment was performed on male Wistar rats (60 animals). Exposed animals were divided into 5 groups, 12 animals in each (group 1, a single inhalation exposure; group 2, multiple inhalation exposure; group 3, oral exposure; groups 4 and 5 were exposed to bi-distilled water in a similar way, via inhalation and orally). When analyzing tissue images, we estimated first-, second- and third-order elements. Statistical significance of differences was estimated with Mann - Whitney U-test. Quantitative risk assessment (R) was performed taking into account probability $(p)$ and severity (q) of pathomorphological changes in tissues.

We established that pathomorphological disorders might occur in lung tissue taking into account identification of all elements in all images for all experimental groups; the probability varied from 0.16 to 1.2. The total risk of lung diseases amounted to $1.0 \cdot 10^{-3}$ (average risk) under single inhalation exposure to a concentration equal to 0.001CL50; multiple inhalation exposure, $8.1 \cdot 10^{-3}$ (high risk, oral exposure to a dose equal to $0.1 L D_{50}, 2.5 \cdot 10^{-2}$ (high risk).

Therefore, image analysis allows quantitatively assessing risks of diseases in critical organs and systems caused by exposure to metal-containing nanoparticles.

Key words: metal-containing nanoparticles, health risk factors, copper oxide, inhalation exposure, target organs, alveolar pattern, dendrite geometry, damage to lungs, microscopy, image analysis.

Nanomaterials are widely used in multiple technologies and many industrial branches on the international and national levels; their use exerts significant influence on various spheres of economic activity and makes for their development [1]. Nanomaterials, including metal- containing ones, are in high demand due to unique physical and chemical properties of nanoparticles related to their small size, big surface area, shape, surface charge, etc. At the same time these properties that are typical for nanomaterials also result in their great pene-

(c) Zaitseva N.V., Zemlyanova M.A., Ignatova A.M., Stepankov M.S., Koldibekova Yu.V., 2021

Nina V. Zaitseva - Academician of the Russian Academy of Sciences, Doctor of Medical Sciences, Professor, Scientific Director (e-mail: znv@ffrisk.ru; tel.: +7 (342) 237-25-34; ORCID: https://orcid.org/0000-0003-2356-1145).

Marina A. Zemlyanova - Doctor of Medical Sciences, Chief Researcher acting as the Head of the Department for Bio-chemical and Cytogenetic Diagnostic Techniques (e-mail: zem@fcrisk.ru; tel.: +7 (342) 236-39-30; ORCID: http://orcid.org/0000-0002-8013-9613).

Anna M. Ignatova - Doctor of Technical Sciences, Researcher at the Department for Biochemical and Cytogenetic Diagnostic Techniques; Researcher at the Laboratory for Physical Strength Basics (e-mail: iampstu@gmail.com; tel.: +7 (342) 236-39-30; ORCID: http://orcid.org/ 0000-0001-9075-3257).

Mark S. Stepankov - Researcher at the Department for Biochemical and Cytogenetic Diagnostic Techniques (e-mail: stepankov@fcrisk.ru; tel.: +7 (950) 448-66-26; ORCID: https://orcid.org/0000-0002-7226-7682).

Yuliya V. Koldibekova - Candidate of Biological Sciences, Senior researcher acting as the Head of the Laboratory for Metabolism and Pharmacokinetics at the Department for Biochemical and Cytogenetic Diagnostic Techniques (e-mail: koldibekova@fcrisk.ru; tel.: +7 (342) 237-18-15; ORCID: http://orcid.org/0000-0002-3924-4526). 
trability and it, in its turn, can lead to their greater toxicity when they are introduced into a human body at any stage in production and consumption [2]. Volumes of metal-containing nanoparticles consumption are only growing and it causes their active introduction into environmental objects and, consequently, results in elevated health risks.

Nano-sized copper oxide (nano-CuO) is a widespread metal-containing nanomaterial; it is used in various production spheres as a component in sensors (49\%), catalysts $(20 \%)$, surfactants $(6 \%)$, anti-microbial substances (4\%), specific dyes $(21 \%)$, and other products [3-8]. The research work [9] revealed that copper oxide nanoparticles penetrated a human body predominantly via inhalation or oral introduction (with drinking water). Negative effects produced on critical organs and systems by exposure to ultra small copper oxide nanoparticles were described in the papers [10-14]. Available data indicate that exposure to copper oxide nanoparticles produces toxic and genotoxic effects, both under acute single exposure and multiple one. Significant changes occur in lung tissues both under inhalation and oral exposure [15]. Micro-sized copper oxide particles belong to moderately toxic substances (the $3^{\text {rd }}$ hazard degree) regarding their hazards for human health [13] and it provides some understanding on maximum permissible no-effect concentrations; still, it is not enough for predicting risks of morphofucntional disorders in critical organs and systems, primarily the lungs.

Risks of morphofucntional changes in critical organs under exposure to metal-containing nano-particles are estimated via experiments performed on laboratory animals that are used as biological models. Changes in tissues are estimated in such experiments as per conventional procedures using histological preparations and these estimations are rather subjective and lack quantitative estimation parameters; it makes predicting and ranking risks of pathomorphological changes more difficult. «Image analysis» is a set of procedures that allows the most objective quantitative assessment of changes in tissues using computer vision.

Given that, it seems vital to develop approaches to quantitative assessment of risks that negative effects might be produced on tissues in target organs, notably the lungs, for different introduction ways and multiplicity of exposure to nanoparticles; the most efficient analysis techniques are to be well-grounded.

Our research goal was to reveal and quantitatively assess risks of the lung diseases in rats under exposure to metal-containing nanoparticles (on the example of nano-sized copper oxide $\mathrm{CuO}$ ) using image analysis procedure.

Data and methods. Nanodispersed copper oxide (nano $\mathrm{CuO}$ ) was used in the studies on revealing and quantitatively assessing risks of morphofucntional changes in lung tissues under inhalation and oral exposure to metal-containing nanoparticles. We used powder nanodispersed copper oxide II (CAS 1317-38-0) with average particle size being 45.86 nanometers and particle sphericity coefficient being 0.59 (Sigma-Aldrich, USA). Particles composure and morphometric properties were determined with scanning electronic microscopy performed on S-3400N high resolution scanning microscope («HITACHI», Japan) and with X-ray spectral microprobe analysis («Bruker», Germany).

Toxic effects produced by nano-sized copper oxide were examined in experiments that involved inhalation (single and multiple, during 14 days) and oral (20-day) exposure according to methodical guidelines and guides ${ }^{1,2}$. Water suspensions based on bi-distilled water (TU 6-09-2502-77) were used for introduction. Prior to exposure, suspensions were preliminarily homogenized using SonopulsHd 3200 (Bandelin, Germany) ultrasound device under room temperature; the procedure was performed for

\footnotetext{
${ }^{1}$ MR 1.2.2522-09. Methodical recommendations on revealing nanomaterials that are potentially hazardous for human health / approved by the RF Chief Sanitary Inspector on July 1, 2009). Bulletin of regulatory and methodical documents issued by the State Sanitary and Epidemiologic Surveillance Service, 2010, vol. 1, pp. 25-45 (in Russian).

${ }^{2}$ MU 1.2.2520-09. Toxicological-hygienic assessment of nanomaterials safety: methodical guidelines. Moscow, The Federal Center for Hygiene and Epidemiology of Rospotrebnadzor, 2009, 35 p. (in Russian).
} 
2 minutes in uninterrupted pulsation mode with $20 \mathrm{kHz}$ frequency.

Experimental exposure was performed on male Wistar rats (60 animals overall), aged 8 weeks and with body weight being 180-250 g; all the experiments were performed in conformity with the requirements fixed by the European Convention for the Protection of Vertebrate Animals used for Experimental and other Scientific Purposes (ETS No. 123) and the Ethical Committee of the federal scientific Center for Medical and Preventive Health Risk Management Technologies. Animals were kept in between the exposure sessions in accordance with the requirements SR 2.2.1.3218-14 ${ }^{3}$ in an vivarium in polyethylene cages under $22^{\circ} \mathrm{C}$ and relative air humidity being $55 \%$, light/dark cycle was $12 / 12$. During the whole experiment rats were given conventional feedstuff (solid extruded granules) and pure water.

Experimental research involved dividing animals into 5 groups, 12 animals in each; the test group 1 underwent single inhalation exposure to nano-sized copper oxide; the test group 2, multiple inhalation exposure to nano-sized copper oxide; the test group 3, multiple oral exposure to nano-sized copper oxide; the reference groups 4 and 5 were exposed to bi-distilled water via inhalation and orally accordingly.

Single and multiple inhalation exposure to the examined nanomaterial was performed in a full-body chamber (TSE Systems GmbH, Germany) according to the state standard GOST 32646-2014 $4^{4}$. Chamber volume amounted to $0.1 \mathrm{~m}^{3}$. Suspension was fed into the chamber in concentration equal to $1.25 \mathrm{mg} / \mathrm{m}^{3}$ as an aerosol via mechanical injection with a spay nozzle. Air inflow was continuous during each exposure session and air was fed at a speed equal to $10 \mathrm{dm}^{3} / \mathrm{min}$ (oxygen concentration was not lower than $19 \%$, and carbon dioxide, $1 \%$ ); water suspension of nano-CuO was fed at a speed equal to $0.4 \mathrm{~cm}^{3} / \mathrm{min}$; air outflow speed was
$10 \mathrm{dm}^{3} / \mathrm{min}$; pressure fluctuation inside the chamber were equal to 0.4 millibar; temperature inside the chamber was $22-25^{\circ} \mathrm{C}$. Actual nano- $\mathrm{CuO}$ concentration in the chamber amounted to $1.17 \pm 0.18 \mathrm{mg} / \mathrm{m}^{3}$ (0.001 CL50). Single inhalation exposure lasted for 4 hours. Multiple inhalation exposure was performed via daily sessions, 6 hours each, for 14 days altogether. Multiple oral exposure was performed with cumulation examination procedure as per Lim [16] (once a day and every day for 20 days). Initial introduction dose according to the procedure amounted to $250 \mathrm{mg} / \mathrm{kg}$ of body weight $\left(0.1 \mathrm{LD}_{50}\right)$. Every 5 days subsequent doses were increased by 1.5 times. Total oral exposure dose introduced over 20 days amounted to $1,275 \mathrm{mg} / \mathrm{kg}$ of body weight a day $\left(0.5 \mathrm{LD}_{50}\right)$. Animals were not given and feedstuff or water during exposure sessions.

After the experiments were completed, the lungs were taken out via total evisceration as per Shore and then fixated in $10 \%$ water neutral formalin solution; after that, the samples were dehydrated in spirits with upward concentration and then saturated with chloroform and paraffin and soaked in «Histomix» homogenized paraffin medium. Slices that were $4 \mu \mathrm{m}$ thick were obtained with JUNG SM 2000R sliding microtome (Leica, Germany), dyed with Ehrlich's hematoxylin and eosin. Samples were examined and their images were taken with Axiostar transmittedlight microscope (Carl Zeiss, Germany).

To reveal and quantitatively assess morphological changes in tissues, we applied image analysis based on computer vision using Image J-FiJi universal software (open-code software developed by Wayne Rasband, National Institutes of Health, USA).

Frequency of pathomorphological changes that didn't have any apparent specific size parameters or calculated parameters was assessed quantitatively using mathematical analysis

\footnotetext{
${ }^{3}$ SR 2.2.1.3218-14. Sanitary-epidemiologic requirements to layout, equipment, and maintenance of experimental biological clinics (vivariums). KODEKS: an electronic fund for legal and reference documentation. Available at: https:// docs.cntd.ru/document/420219460 (16.06.2021) (in Russian).

${ }^{4}$ GOST 32646-2014. Procedures for testing effects produced by exposure to chemicals on a human body. OECD guidelines for the testing of chemicals. Acute Inhalation toxicity - acute toxic class (ATC) method. KODEKS: an electronic fund for legal and reference documentation. Available at: https://docs.cntd.ru/document/1200116047 (16.06.2021) (in Russian).
} 
procedures. To do that, we determined whether there were basic components of histological images in lung tissues:

- first-order elements: negative space, that is, space that is not filled with tissue component; it allows estimating sizes and morphology of alveolar spaces; morphological parameters of alveolar spaces might not change in great details, and at initial stages in pathomorphological changes alveolar spaces only decrease in size while geometric patterns parameters remain unchanged $[17,18]$;

- second-order elements: tissue mass that was described with plane figures that created alveolar patterns and were estimated with dendritic geometry procedures using the following parameters: a ratio between an average length of a branch and a length of the longest branch, a ratio between a number of intersections and a number of branches and per cent of triple and quaternary intersections in the overall number of intersections. Images were preliminarily processed with binarization and skeletonization techniques $[19,20]$;

- third-order elements: cell nucleuses with their positions against each other allowing making a judgment on whether cells were evenly located in tissue structure, that is, the more pathologic changes occur, the more fluctuations are detected where cell nucleuses are located the closest to each other.

Statistical significance of differences between group parameters was estimated with Mann - Whitney U-test with preset significance being 0.05 since data obtained via using the above-listed image analysis procedures were not distributed evenly and could be interpreted only using non-parametric statistics. Statistical estimation was performed with BioStat 7.0 (Analyst Soft Inc.).

Quantitative risk assessment $(R)$ was performed taking into account probability $(p)$ and severity $(q)$ of pathomorphological disorders occurring in tissues as per the following formula: $R=p \cdot q$. Severity of disorders was estimated as per weighted average parameter ranging from 0 to 1 . Obtained risk values being lower than $1 \cdot 10^{-6}$ meant risk was negligible; from $1 \cdot 10^{-6}$ to $1 \cdot 10^{-4}$, low risk; from $1 \cdot 10^{-4}$ to $1 \cdot 10^{-3}$, average risk; higher than $1 \cdot 10^{-3}$, high risk $^{5}$. Assessment was performed as per elements of all the above-mentioned orders and for all the groups. Risk was characterized as per the highest parameter detected for each experimental group as per analyzed first-order, second-order and third-order elements.

Results and discussion. Accomplished experimental research on inhalation and oral exposure to nano- $\mathrm{CuO}$ allowed obtaining histological images of rats' lung tissues. Figure 1 shows lung tissues taken from rats from the test and reference groups.

According to classic pathomorphological assessment (Table 1) there are no pathological changes in lung tissues taken from animals from reference groups 4 and 5. Pathomorphological changes in lung tissues were detected in animals from groups that underwent single and multiple inhalation exposure (Groups 1 and 2) and oral exposure (Group No. 3). Lung tissues taken from animals from all the test groups excluding reference ones (Groups 4 and 5) have signs of lymphoid tissue hyperplasia associated with bronchial walls with admixture of multiple eosinophils. There was also additional pigment accumulation in macrophages and vascular inflammation detected in Groups 2 and 3. Besides, we revealed certain peculiarities in lung tissues changes in Group 2 (focal interstitial inflammation and alveolitis) and in Group 3 (abscess).

Table 2 contains the results obtained via analyzing images of lung tissues when assessing first-order image elements.

Studies on first-order elements occurring in lung tissues allowed revealing that parameters obtained for Groups 2 and 3, that is, multiple inhalation and oral exposure, we statistically authentically different from reference Groups 4 and 5. Parameters obtained for Group 1 were not different from that contained for reference groups.

${ }^{5} \mathrm{R}$ 2.1.10.-1920-04. The Guide on assessing health risks caused by exposure to chemicals that pollute the environment. Moscow, The RF Public Healthcare Ministry Centre for State Sanitary and Epidemiologic Surveillance Publ., 2004, 143 p. (in Russian). 


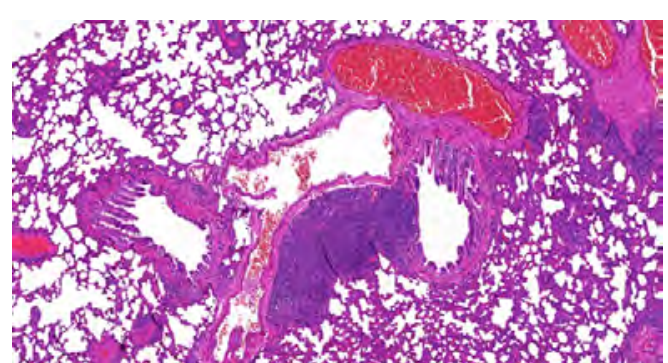

$a$

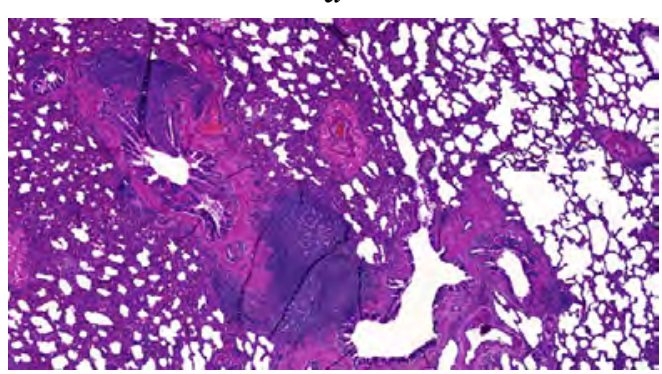

$C$

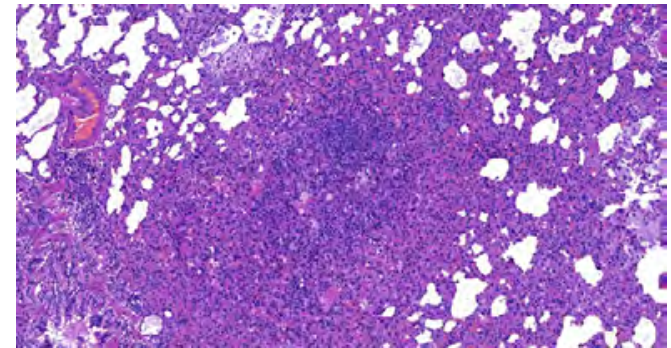

$b$

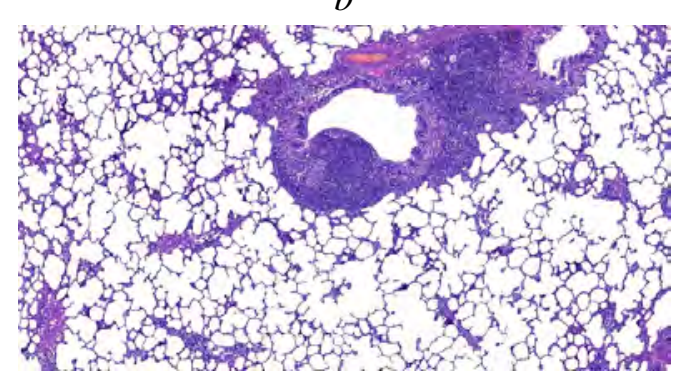

$d$

Figure 1. Rats' lung tissues under exposure to nano-sized copper oxide particles, $\mathrm{x} 100$ : a is Group 1 (single inhalation exposure); $\mathrm{b}$ is Group 2 (multiple inhalation exposure); $\mathrm{c}$ is Group 3 (multiple oral exposure), $\mathrm{d}$ are Groups 4 and 5 (reference)

Table 1

Results obtained via pathomorphological analysis of lung tissues taken from Wistar rats in experiments on impacts exerted by exposure to nano- $\mathrm{CuO}$

\begin{tabular}{|l|l|}
\hline \multicolumn{1}{|c|}{ Group } & \multicolumn{1}{|c|}{ Lung tissues } \\
\hline Group 1 (single inhalation) & $\begin{array}{l}\text { Lymphoid tissue hyperplasia associated with bronchial walls with admixture of multiple } \\
\text { eosinophils }\end{array}$ \\
\hline Group 2 (multiple inhalation) & $\begin{array}{l}\text { Lymphoid tissue hyperplasia associated with bronchial walls with admixture of multiple } \\
\text { eosinophils. Disseminated vasculitis. Accumulated brown pigment in cytoplasm of multi- } \\
\text { ple macrophages. Focal interstitial inflammation, alveolitis }\end{array}$ \\
\hline Group 3 (multiple oral) & $\begin{array}{l}\text { Lymphoid tissue hyperplasia associated with bronchial walls with admixture of multiple } \\
\text { eosinophils. Disseminated vasculitis. Accumulated brown pigment in cytoplasm of multi- } \\
\text { ple macrophages. Focal suppurative-destructive process }\end{array}$ \\
\hline Groups 4 and 5 (reference) & Without visible morphological changes \\
\hline
\end{tabular}

Table 2

Results obtained via using computer vision for analyzing images of Wistar rats' lung tissues under exposure to nano- $\mathrm{CuO}$ as per first-order elements (significance is 0.05 , comparison as per Mann - Whitney, $U_{\mathrm{cr}} \leq 9$ )

\begin{tabular}{|l|c|c|c|c|}
\hline \multicolumn{1}{|c|}{ Estimated parameter } & \multicolumn{3}{c|}{ Group } \\
\cline { 2 - 5 } & 1 & 2 & 3 & 4 and 5 \\
\hline Negative space square $\left(S_{N S}\right), \%$ & $\begin{array}{c}49.97 \pm 7.55 \\
\begin{array}{l}|c| \\
* * * U=4 ; p=0.001\end{array}\end{array}$ & $\begin{array}{c}27.62 \pm 7.86 \\
* U=3 ; p=0.007 \\
* * * * U=6 ; p=0.02\end{array}$ & $\begin{array}{c}15.54 \pm 2.48 \\
* U=1 ; p=0.009 \\
* * U=1 ; p=0.011\end{array}$ & $56 \pm 5.33$ \\
\hline $\begin{array}{l}\text { Tissue component square } \\
\left(100-S_{N S}\right), \%\end{array}$ & $50.03 \pm 12.3$ & $72.38 \pm 5.59$ & $85.46 \pm 5.55$ & $63.06 \pm 10.93$ \\
\hline $\begin{array}{l}\text { Total coefficient of first-order elements } \\
S_{N S} /\left(100-S_{N S}\right)\end{array}$ & $1.39 \pm 0.22$ & $\begin{array}{c}* 0.47 \pm 0.04 \\
p=0.02\end{array}$ & $\begin{array}{c}* 0.17 \pm 0.08 \\
p=0.009\end{array}$ & $1.55 \pm 0.13$ \\
\hline $\begin{array}{l}\text { Probability of pathomorphological } \\
\text { changes in tissue }(p)\end{array}$ & 0.08 & 0.25 & 0.50 & - \\
\hline Risk of a disease occurrence $(R)$ & $8 \cdot 10^{-5}$ & $2.5 \cdot 10^{-4}$ & $5 \cdot 10^{-4}$ & - \\
\hline
\end{tabular}

$\mathrm{N}$ ot e : * means authentic difference from reference groups; ** means authentic difference from Group 1; *** means authentic difference from Group $2 ; * * * *$ means authentic difference from Group 3. 
Table 3

Results obtained via using computer vision for analyzing images of Wistar rats' lung tissues under exposure to nano- $\mathrm{CuO}$ as per second-order elements (significance is 0.05 , comparison as per Mann - Whitney, $\left.U_{\mathrm{cr}} \leq 9\right)$

\begin{tabular}{|c|c|c|c|c|}
\hline \multirow{2}{*}{ Estimated parameter } & \multicolumn{4}{|c|}{ Group } \\
\hline & 1 & 2 & 3 & 4 and 5 \\
\hline $\begin{array}{l}\text { Ratio of a total number of inter- } \\
\text { section to a total number of } \\
\text { brunches }\end{array}$ & $\begin{array}{c}0.49 \pm 0.09 \\
* U=7 ; p=0.002\end{array}$ & $\begin{array}{c}0.48 \pm 0.05 \\
* U=7 ; p=0.003\end{array}$ & $\begin{array}{c}0.54 \pm 0.03 \\
* U=8 ; p=0.006\end{array}$ & $0.38 \pm 0.08$ \\
\hline $\begin{array}{l}\text { Ratio of an average length of a } \\
\text { brunch to the maximum length }\end{array}$ & $\begin{array}{c}0.19 \pm 0.08 \\
* U=1 ; p=0.003\end{array}$ & $\begin{array}{c}0.25 \pm 0.09 \\
* U=2 ; p=0.001\end{array}$ & $\begin{array}{c}0.16 \pm 0.04 \\
* U=1 ; p=0.001\end{array}$ & $0.54 \pm 0.01$ \\
\hline $\begin{array}{l}\text { A share of triple intersec- } \\
\text { tions, } \%\end{array}$ & $\begin{array}{c}25.56 \pm 5.23 \\
* U=5 ; p=0.009\end{array}$ & $\begin{array}{c}23.42 \pm 6.27 \\
* U=5 ; p=0.004\end{array}$ & $61.60 \pm 5.74$ & $48.92 \pm 3.47$ \\
\hline $\begin{array}{l}\text { A share of quadrupole intersec- } \\
\text { tions, } \%\end{array}$ & $\begin{array}{c}8.56 \pm 6.11 \\
* U=4 ; p=0.003\end{array}$ & $\begin{array}{c}10.5 \pm 7.43 \\
* U=4 ; p=0.006\end{array}$ & $18.08 \pm 4.26$ & $14.00 \pm 5.86$ \\
\hline $\begin{array}{l}\text { Probability of pathomor- } \\
\text { phological changes developing } \\
\text { in tissue }(p)\end{array}$ & 0.08 & 0.66 & - & - \\
\hline Risk of a disease occurrence $(R)$ & $8.0 \cdot 10^{-4}$ & $6.6 \cdot 10^{-3}$ & - & - \\
\hline
\end{tabular}

Note : * means authentic difference from reference groups; ** means authentic difference from Group 1; *** means authentic difference from Group 2; **** means authentic difference from Group 3.

Total coefficient of first-order elements (integral parameter) amounted to $0.47 \pm 0.04$ and $0.17 \pm 0.08$ in Groups that underwent multiple inhalation and oral exposure accordingly and it was by 3.3-9.2 times lower than the reference value. The detected trend indicates that frequency and intensity of damage to lung tissues is by 2.0 and 2.8 times higher accordingly under oral exposure than under inhalation one. Risk of diseases occurrence caused by disorders in lung tissues detected via image analysis amounted to $8 \cdot 10^{-5}$ and $2.5 \cdot 10^{-4}$ under inhalation exposure and it meant low and average risk accordingly; it amounted to $5 \cdot 10^{-4}$ under oral exposure (average risk).

Table 3 contains the results obtained via analyzing images of lung tissues when secondorder elements were assessed.

Computer vision used for analyzing lung tissues and detecting second-order elements provided an opportunity to establish that ratios between the total number of intersections and total number of brunches and between an average brunch length and the maximum brunch length differed in Groups 1, 2, and 3 from groups 4 and 5 , but there were no difference between the three former groups. Shares of triple and quadrupole intersections were
1.8 times lower than the reference parameter only in Groups 1 and 2 (inhalation exposure). Values were not different between these two groups but changes parameters were registered 2 times more frequently under multiple inhalation exposure than under single one. Risk of diseases that might occur in lung tissues was determined via image analysis procedure and varied from $8.0 \cdot 10^{-4}$ to $6.6 \cdot 10^{-3}$ in Groups 1 and 2, or under inhalation exposure, and it indicated there was an average and high risk accordingly.

Table 4 contains the results obtained via analyzing images of lung tissue when thirdorder elements were analyzed.

Computer vision used for identifying third-order elements in lung tissue allowed establishing that a number of neighboring cells were authentically different in Groups 2 and 3 from the reference Groups 4 and 5. This parameter was 1.5 times higher in Group 3 (multiple oral exposure) than in the reference groups, and 1.7 times higher in Group 2 (multiple inhalation exposure). Disorders in lung tissues were registered 2 times more frequently after multiple oral exposure (Group 3) than after multiple inhalation exposure (Group 2). 
Table 4

Results obtained via using computer vision for analyzing images of Wistar rats' lung tissues under exposure to nano- $\mathrm{CuO}$ as per third-order elements (significance is 0.05 , comparison as per Mann - Whitney, $\left.U_{\mathrm{cr}} \leq 9\right)$

\begin{tabular}{|l|c|c|c|c|}
\hline \multicolumn{1}{|c|}{ Estimated parameter } & \multicolumn{4}{|c|}{ Group } \\
\cline { 2 - 5 } & 1 & 2 & 3 & 4 and 5 \\
\hline $\begin{array}{l}\text { Average number of neighboring } \\
\text { cells, units/cell }\end{array}$ & $\begin{array}{c}9.6 \pm 1.43 \\
U=368 ; p=0.11\end{array}$ & $\begin{array}{c}19.0 \pm 2.75 \\
* U=117 ; p=0.099\end{array}$ & $\begin{array}{c}* U=107.0 \pm 2.98 \\
* * * U=128 ; p=0.088\end{array}$ & $11.66 \pm 2.18$ \\
\hline $\begin{array}{l}\text { Probability of pathomor- } \\
\text { phological changes developing } \\
\text { in tissue }(p)\end{array}$ & - & 0.25 & 0.5 & - \\
\hline $\begin{array}{l}\text { Risk of a disease } \\
\text { occurrence }(R)\end{array}$ & - & $1.2 \cdot 10^{-2}$ & $2.5 \cdot 10^{-2}$ & - \\
\hline
\end{tabular}

Note : * means authentic difference from reference groups; ** means authentic difference from Group 1; *** means authentic difference from Group $2 ; * * * *$ means authentic difference from Group 3.

Use of image analysis procedure to identify first-, second- and third-order elements revealed there was a possibility that pathomorphological disorders might occur in lung tissues in all three test groups but frequency of detected disorders was different under inhalation and oral exposure. Thus, damage to lung tissue was registered 1.2 times more frequently under oral exposure to nano- $\mathrm{CuO}$ than under multiple inhalation exposure to it. Overall, disorders in lung tissues were registered 7.2 times more frequently under multiple inhalation exposure than under single one. As a result, identification of all elements in images taken into account, probability of disorders occurrence varied from 0.16 to 1.2 . The total risk of lung diseases, taking into account severity of identified elements, amounted to $1.0 \cdot 10^{-3}$ under single inhalation exposure (average risk); $8.1 \cdot 10^{-3}$, under multiple inhalation exposure (high risk); $2.5 \cdot 10^{-2}$, under multiple oral exposure (high risk).

We comparatively analyzed results obtained via image analysis procedure and classic pathomorphological assessment of lung tissues that showed morphofunctional changes in lung tissue and risk of diseases caused by exposure to nano- $\mathrm{CuO}$. The analysis revealed that single inhalation exposure resulted in average risk of lung diseases and it corresponded to such pathomorphological changes in lung tissue as lymphoid tissue hyperplasia in the bronchial wall combined with eosinophilia. Multiple inhalation and oral exposure caused high risks of disease occurrence and this risk was 3 times higher under oral exposure than under inhalation one. It corresponded to the following pathomorphological changes in lung tissue: focal interstitial inflammation and alveolitis under multiple inhalation exposure and focal suppurative-destructive processes under multiple oral exposure.

Conclusion. Use of image analysis procedure for examining consequences caused by exposure to metal-containing nanoparticles allows identifying elements of morphofunctional changes in lung tissues that belong to different orders. This identification provides an opportunity to quantitatively assess risks of diseases in critical organs and systems. Quantitative assessment of risks related to disease occurrence was accomplished in the present research with image analysis procedure for exposure that was different either as per duration or a way of metal-containing particles introduction into a body (on the example of nano- $\mathrm{CuO}$ ). This assessment allowed establishing that single inhalation exposure to the examined nanomaterial in concentration equal to $1.2 \mathrm{mg} / \mathrm{m}^{3}$ 
(0.001CL50) caused average risk of lung diseases occurrence; multiple inhalation exposure in the same concentration that lasted for 14 days resulted in high risk. Oral exposure to a dose equal to $250 \mathrm{mg} / \mathrm{kg}$ of a body weight $\left(0.1 \mathrm{LD}_{50}\right)$ that lasted for 20 days also caused high risk of lung diseases occurrence and this risk was 3.1 times higher than that caused by multiple inhalation exposure.

Funding. The research was not granted any sponsor support.

Conflict of interests. The authors declare there is no any conflict of interests.

\section{References}

1. Benefits and Applications. Official website of the United States National Nanotechnology Initiative. Available at: https://www.nano.gov/you/nanotechnology-benefits_(21.05.2021) (in Russian).

2. Sukhanova A., Bozrova S., Sokolov P., Berestovoy M., Karaulov A., Nabiev I. Dependence of Nanoparticle Toxicity on Their Physical and Chemical Properties. Nanoscale Research Letters, 2018, vol. 13, no. 44, 21 p. DOI: 10.1186/s11671-018-2457-x

3. Bernhardt E.S., Colman B.P., Hochella M.F., Cardinale B.J., Nisbet R.M., Richardson C.J., Yin L. An ecological perspective on nanomaterial impacts in the environment. Journal of Environmental Quality, 2010, vol. 39, no. 6, pp. 54-65. DOI: 10.2134/jeq2009.0479

4. Brix K.V., Gerdes R.M., Adams W.J., Grosell M. Effects of copper, cadmium, and zinc on the hatching success of brine shrimp (Artemia franciscana). Archives of Environmental Contamination and Toxicology, 2006, vol. 51, no. 4, pp. 580-583. DOI: 10.1007/s00244-005-0244-z

5. Failla M.L. Trace elements and host defense: recent advances and continuing challenges. Journal of Nutrition, 2003, vol. 133, no. 5 (1), pp. 1443S-1447S. DOI: 10.1093/jn/133.5.1443S

6. Ameh T., Sayes C.M. The potential exposure and hazards of copper nanoparticles: A review. Environmental Toxicology and Pharmacology, 2019, no. 71, pp. 103220. DOI: 10.1016/j.etap.2019.103220

7. Sutunkova M.P. Experimental studies of toxic effects' of metallic nanoparticles at iron and nonferrous industries and risk assessment for workers` health. Gigiena i sanitariya, 2017, vol. 96, no. 12, pp. 1182-1187 (in Russian).

8. Zeinalov O.A., Kombarova S.P., Bagrov D.V., Petrosyan M.A., Tolibova G.Kh., Feofanov A.V., Shaitan K.V. About the influence of metal oxide nanoparticles on living organisms physiology. Obzory po klinicheskoi farmakologii i lekarstvennoi terapii, 2016, no. 3, pp. 24-33 (in Russian).

9. Chambers A., Krewski D., Birkett N., Plunkett L., Hertzberg R., Danzeisen R., Aggett P.J., Starr T.B. [et al.]. An exposure-response curve for copper excess and deficiency. Journal of Toxicology and Environmental Health Part B, 2010, vol. 13, no. 7-8, pp. 546-578. DOI: 10.1080/10937404.2010.538657

10. Stern B.R., Solioz M., Krewski D., Aggett P., Aw T.-C., Baker S., Crump K., Dourson M. [et al.]. Copper and human health: biochemistry, genetics, and strategies for modeling dose-response relationships. Journal of Toxicology and Environmental Health Part B, 2007, vol. 10, no. 3, pp. 157-222. DOI: $10.1080 / 10937400600755911$

11. Kopytenkova O.I., Levanchuk A.V., Tursunov Z.Sh. Health risk assessment for exposure to fine dust in production conditions. Meditsina truda i promyshlennaya ekologiya, 2019, vol. 59, no. 8, pp. 458-462 (in Russian).

12. Andreev G.B., Minashkin V.M., Nevskii I.A., Putilov A.V. Materials based on nanotechnologies: potential risk at production and use. Rossiiskii khimicheskii zhurnal, 2008, vol. 52, no. 5, pp. 32-38 (in Russian).

13. Karkishchenko N.N. Nanobezopasnost': novye podkhody k otsenke riskov i toksichnosti nanomaterialov [Nanosafety: new approaches to assessing risks and toxicity of nanomaterials]. Biomeditsina, 2009, no. 1, pp. 5-27 (in Russian).

14. Tomilina I.I., Gremyachikh V.A., Grebenyuk L.P., Golovkina E.I., Klevleeva T.R. Toxicological study of metal and metal oxide nanoparticles. Trudy Instituta biologii vnutrennikh vod RAN, 2017, vol. 80, no. 77, pp. 45-57 (in Russian).

15. Park J.W., Lee I.-C., Shin N.-R., Jeon C.-M., Kwon O.-K., Ko J.-W., Kim J.-C., Oh S.-R. Copper oxide nanoparticles aggravate airway inflammation and mucus production in asthmatic mice via MAPK signaling. Nanotoxicology, 2016, no. 10, pp. 445-452. DOI: 10.3109/17435390.2015.1078851 
16. Kevin H., Stewart W. Acute, Sub-Acute, Sub-Chronic and Chronic General Toxicity Testing for Preclinical Drug Development. A Comprehensive Guide to Toxicology in Preclinical Drug Development, 2013, chapter 5, pp. 87-105.

17.Zaitseva N.V., Zemlyanova M.A., Ignatova A.M., Stepankov M.S. Morphological changes in lung tissues of mice caused by exposure to nano-sized particles of nickel oxide. Nanotechnologies in Russia, 2018, no. 7-8, pp. 393-399. DOI: 10.1134/S199507801804016X

18. Velikorodnaya Yu.I., Pocheptsov A.Ya. Nanoparticles as a potential threat to the environment. Meditsina ekstremal'nykh situatsii, 2015, vol. 53, no. 3, pp. 73-77 (in Russian).

19. Ashburner J. A fast-diffeomorphic image registration algorithm. Neuroimage, 2007, vol. 5, no. 38 (1), pp. 95-113. DOI: 10.1016/j.neuroimage.2007.07.007

20. Bekkers E.J., Lafarge M.W., Veta M., Eppenhof K.A., Pluim J.P., Duits R. Roto-translation covariant convolutional networks for medical image analysis. Medical Image Computing and Computer Assisted Intervention, 2018, no. 1, pp. 440-448 (in Russian).

Zaitseva N.V., Zemlyanova M.A., Ignatova A.M., Stepankov M.S., Koldibekova Yu.V. Metalcontaining nanoparticles as risk factors causing pathomorphological changes in internal organs tissues in an experiment. Health Risk Analysis, 2021, no. 2, pp. 114-122. DOI: 10.21668/health.risk/2021.2.11.eng

Received: 21.04 .2021

Accepted: 09.06.2021

Published: 30.09.2021 